\title{
Убийство Соломона Михоэлса: к проблеме подлинности и достоверности исторических источников
}

\author{
М.К. Бисенгалиев \\ МОО «Платоновское философское общество», независимый исследователь \\ 125047, Россия, Москва, Миусская пл., 6, корп. 6 \\ E-mail: bermont_avalov@mail.ru
}

\begin{abstract}
Аннотация. В статье представлен обзор ожесточенной полемики среди исследователей эпохи позднего сталинизма о причинах гибели Соломона Михоэлса (Шлойме Вовси) - всемирно известного советского актёра, художественного директора Московского государственного еврейского театра (ГОСЕТа), а также видного общественно-политического деятеля, в том числе председателя «Еврейского антифашистского комитета». Дается критический анализ происхождения документов, на основании которых исследователями делаются спорные обобщающие выводы. Сделан вывод о недостоверности ряда исторических источников, относящихся к убийству Михоэлса. В этой связи поставлен вопрос о необходимости нового пересмотра «дела Михоэлса». Приводятся обширная библиография, характеристика источников и историография рассматриваемого вопроса.
\end{abstract}

Ключевые слова: С. Михоэлс, И. Сталин, Еврейский антифашистский комитет, источниковедческий анализ, исторический источник, критика источников.

Для цитирования: Бисенгалиев М.К. 2021. Убийство Соломона Михоэлса: К проблеме подлинности и достоверности источников. Via in tempore. История. Политология, 48 (1): 177-187. DOI: $10.52575 / 2687-0967-2021-48-1-177-187$.

\section{Assassination of Solomon Mikhoels: About the problem of authenticity and reliability of the historical primary sources}

\author{
Marat K. Bisengaliev \\ Plato Philosophy Society, independent researcher \\ 6 k. 6, Miusskaya sq., Moscow, 125047, Russia \\ E-mail: bermont_avalov@mail.ru
}

\begin{abstract}
There is a great deal of debate among researchers of the late Stalin era about whether there are good reasons to believe that Stalin decided to kill the Jewish leader Solomon Mikhoels, which was a famous Soviet actor at the time, artistic director of the Moscow State Jewish Theater ("GOSET") and head of the "Jewish Anti-fascist Committee". This article provides an overview of this debate and the variety of the research strategies currently in use. Particular attention to the critical analysis of the origin of documents is given; on the basis of which researchers draw controversial generalizing conclusions. It is concluded that a number of historical sources related have been are unreliable and there is no sourcestudy evidence for their legitimate origin. In this regard, the question was raised about the new research of the scientific problem of the assassination of Solomon Mikhoels. An extensive bibliography, characteristics of sources and historiography of the issue under consideration are presented.
\end{abstract}

Keywords: S. Mikhoels, J. Stalin, Jewish Anti-fascist Committee, source-study analysis, a historical source, criticism of sources.

For citation: Bisengaliev M.K. 2021. Assassination of Solomon Mikhoels: About the problem of authenticity and reliability of the historical primary sources. Via in tempore. History and political science, 48 (1): 177-187 (in Russian). DOI: 10.52575/2687-0967-2021-48-1-177-187. 


\section{Введение}

В 2020 году исполнилось 130 лет с рождения Соломона Михоэлса (Шлойме Вовси) - всемирно известного актёра, художественного руководителя Московского ГОСЕТа и официального лидера советской еврейской общественности, первого председателя «Еврейского антифашистского комитета» (далее - ЕАК). Однако, несмотря на широкое исследовательское внимание, в общественной деятельности и гибели Михоэлса остается много загадок.12 января 1948 г. сотрудниками МГБ СССР Михоэлс был убит, а его гибель замаскирована под несчастный случай в автокатастрофе. Причины и обстоятельства этого убийства стали предметом ожесточенных споров среди исследователей эпохи позднего сталинизма. Задачей данной статьи является анализ этой полемики, на основании которого предлагаются обобщающие выводы.

В отечественной историографии из имевшей выраженный антисемитский характер кампании по борьбе с космополитизмом в СССР 1949-1953 гг. исследователи выделяют отдельные проблемно-тематические блоки: от «дела Еврейского антифашистского комитета» (конец 1948 - июль 1952 гг.) и борьбы с «безродными космополитами» в науке и экономике страны (1949-1953 гг.) ${ }^{70}$ - до «дела о сионистском заговоре в МГБ» (1951-1953 гг.), окончившегося «делом врачей» (конец 1952 - апрель 1953 гг.). В большинстве работ эти репрессии рассматриваются как проводимая под личным руководством Сталина единая государственная политика ${ }^{71}$. Одним из главных аргументов единства линии государственного антисемитизма служит преемственное «замыкание круга» от «дела врачей» к «делу» ЕАК. Так, 13 января 1953 г. в сообщении ТАСС на передовице газеты «Правда» было объявлено, что, по данным следствия, ряд «врачей-вредителей» «получил директиву "об истреблении руководящих кадров СССР" из США от организации “Джойнт" через врача в Москве Шимелиовича и известного еврейского буржуазного националиста Михоэлса» ${ }^{72}$. Имя Михоэлса присутствует во всех вышеуказанных «делах». В этой связи убийство службами МГБ СССР в январе 1948 г. Соломона Михоэлса сегодня признается большинством исследователей первым случаем в череде последовавшей с конца того же года цепочки антисемитских репрессий ${ }^{73}$, предпосылки к которым назревали (и «разрабатывались» спецслужбами) в течение ряда предшествующих лет или даже десятилетий.

\section{Предмет и методы исследования}

По мнению автора, правомочность применимости такой общетипологической цепочки «дел» и кампаний к более ранним событиям может быть подвергнута закономерному сомнению. В особенности когда она представлена не как общая тенденция общенациональной политики Советского государства по еврейскому вопросу в первые послевоенные годы, а конкретно по отношению к гибели Михоэлса, т. е. фактически путем экстраполяции в прошлое результатов многолетнего раскручивания маховика общепризнанно фальсификационной следственной машины МГБ и МВД СССР. Связь убийства Михоэлса в январе и ликвидации ЕАК в ноябре 1948 г. с неким «генеральным вектором» предположительной последовательной сталинской политики государственного антисемитизма, несомненно, должна была найти у сторонников этой версии дополнительные документальные

${ }^{70}$ Историографию кампании по борьбе с космополитизмом в СССР см.: [Генина, 2011].

${ }^{71}$ См., напр., работы: [Костырченко 2003a; Лясс, 2007; Brent, Naumov, 2003]. Периодизацию эволюции государственного антисемитизма см.: [Костырченко, 2009, с. 210-288].

72 «Арест группы врачей-вредителей» // Правда [газета], 1953. № 13 (12581) от 13 янв. С. 1; см.: Документ №262 в БД Архива А.Н. Яковлева, URL (доступ от 10.09.2020): <https://www.alexanderyakovlev.org/fond/issues-doc/69982>.

73 Библиографию публикаций о гибели Михоэлса в ХX в. см. в посвященном ему научнобиблиографическом обзоре [Соломон Михоэлс: Библиогр. указ., 2003]. 
подтверждения. И действительно, такие доказательства были найдены и предоставлены как сторонниками, так и скептиками обсуждаемой версии. Таким образом, из множества современных научных и научно-публицистических работ, посвященных гибели С. Михоэлса, мы выделяем две граничные альтернативные и, так сказать, «межеумочную» версии, критическое сопоставление которых приводит к герменевтически важным выводам, в свою очередь ставшим инструментом данного компаративного историкоисточниковедческого исследования. Рассмотрим кратко эти версии.

\section{Версия 1. Гибель С. Михоэлса стоит обиняком от «дела ЕАК» и сталинской политики государственного антисемитизма}

В целом ряде работ гибель Михоэлса связывается с так называемым «делом Аллилуевых», когда в декабре 1947 - январе 1948 гг. А.С., Е.А. и К.П. Аллилуевы подверглись аресту и были осуждены за клевету на вождя Советского правительства. Посредником в передаче этой «дезинформации» на Запад, по мнению следствия, послужил С. Михоэлс, а его «связными» были арестованные в декабре 1947 г. И.И. Гольдштейн и З.Г. Гринберг. Поскольку известно, что Сталин очень болезненно и жестко реагировал на слухи о своей семье и о нем лично, просочившиеся в западную прессу, то, по замечанию ряда исследователей, какие-либо дополнительные побудительные антисемитские мотивы в планах и действиях вождя по отношению к Михоэлсу оказываются излишними или даже не совпадающими с привлекаемыми фактами. Сталин дан санкцию на арест Аллилуевых, согласно свидетельству его дочери С. Аллилуевой, в связи с тем, что они «Знали слишком много, и болтали слишком много. А это на руку врагам...» [Аллилуева, 1990, с. 149].

Согласно заключению В.В. Кожинова, разделяемому и рядом других российских исследователей, «важно заметить, что “вина” Михоэлса в январе 1948 года заключалась не в создании “сионистского центра", а в распространении "клеветы" на Сталина. Имело место <...> “дело Михоэлса - Аллилуевых", а не, скажем, “дело ЕАК”. Только почти год спустя начались аресты участников “сионистского центра", прежде всего членов ЕАК» [Кожинов, 1999].

Израильский историк А.Д. Эпштейн отмечает в этой связи, что выводы исследователей об отношении И.В. Сталина к советскому и мировому еврейству, будучи соотнесенными, «зияют, казалось бы, немыслимыми лакунами» [Эпштейн, 2014, с. 435], поскольку одновременно с убийством Михоэлса именно по инициативе Сталина СССР оказывал будущему государству Израиль не имевшую равных по своим масштабам политическую и военную поддержку: «мы должны как-то соотнести то, что в один и тот же день Сталин и убивает Михоэлса за излишние “сионистские сантименты”, и снабжает сионистов значительной партией оружия, которым они в итоге и выигрывают Войну за независимость - и соотнести это, прямо скажем, непросто» [Эпштейн, 2014, с. 435-436].

Относительно поставленного вопроса определенную обоснованность обретает версия гибели Михоэлса, которую мы обозначили как «межеумочная». Согласно этой версии, антисемитскую ненависть испытывал в то время не сам Сталин, а ряд руководящих кадров МГБ и МВД СССР, которые и подставили под удар Михоэлса, срежиссировав для вождя убедительный сценарий, на основании которого тот и принял решение об устранении Михоэлса.

\section{Версия 2 («межеумочная»). Сталин идет на поводу сведений, фальсифицированных в аппарате МГБ СССР}

Ж.А. Медведев утверждает, что «в январе 1948 года убийство Михоэлса не могло быть связано ни с “делом ЕАК”, ни с “делом врачей”. Этих дел не было даже в зародыше. $<\ldots>$ поводом для решения Сталина могла быть причастность Михоэлса к “делу Аллилуевых", по которому в 1947 году были арестованы почти все родственники самого Сталина по линии его покойной жены Надежды Аллилуевой» [Медведев, 2003, с. 23]. Жорес Мед- 
ведев анализирует документальные свидетельства и приходит к парадоксальному выводу: изложенные в докладной записке Л.П. Берии о гибели Михоэлса сведения, что директива об устранении Михоэлса исходила лично от Сталина, являются политической интригой самого Л.П. Берии и не имеют ничего общего с действительностью: «Не исключено также, что это была не директива, а лишь согласие с предложением, исходившим от самого Абакумова, в ведомстве которого эта “спецоперация" готовилась заранее, до 10 января» [Медведев, 2003, с. 58].

По заключению Жореса А. Медведева, «К записке Берии от 2 апреля 1953 года нельзя относиться как к документу, полно отражающему действительные обстоятельства этого преступления» [Медведев, 2003, с. 24]. Отмечается также, что «рапорт от 14 января 1948 года из секретариата МВД СССР за подписью министра, генерал-полковника Сергея Круглова» [Козлов, Мироненко, 1994, с. 247] об обстоятельствах гибели Михоэлса, как «nервичный документ, достоверность которого не вызывает сомнений, противоречит показаниям Огольцова и Цанавы, приводившимся в записке Берии» [Медведев, 2003, с. 17], а сама «Записка» содержит противоречие: «С одной стороны, по рассказу Абакумова, "Сталин дал мне <Абакумову $>$ срочное задание - быстро организовать работниками МГБ СССР ликвидацию Михоэлса, поручив это специальным лицам. Тогда было известно, что Михоэлс, а вместе с ним и его друг, фамилию которого не помню, прибыли в Минск”. $<\ldots>$ С другой стороны, по показаниям Цанавы, руководивший всей операцией Огольцов прибыл в Минск за день или два до приезда Михоэлса и с уже готовым планом “ликвидации"» [Медведев, 2003, с. 20].

Близкий знакомый С. Михоэлса, некогда сам ставший жертвой кампании против «буржуазных космополитов», А.М. Борщаговский в известной документальной повести «Обвиняется кровь», посвященной этой кампании, также рассматривает версию о том, что Берия инспирировал показания арестованных участников спецоперации (Абакумова, Огольцова и Цанавы) и «позволил им решительно все свалить на Сталина, сделав их самих покорными $<\ldots>$ исполнителями высочайшего приказа» [Борщаговский, 1994, с. 9-10].

Таким образом, согласно рассмотренной версии, убийство Михоэлса было подготовлено спецслужбами и лишь санкционировано Сталиным после представленных ему фиктивных конспирологических доказательств о причастности Михоэлса к делу Аллилуевых.

\section{Версия 3. Сталин - инициатор и организатор убийства Михоэлса по антисемитским убеждениям}

Вероятно, первым систематическим исследованием в данном ракурсе можно смело назвать вышедшую в Иерусалиме в 1995 г. и выдержавшую несколько изданий монографию Ф.М. Лясса [Лясс, 2007], в которой автор на основе системного анализа публицистических источников и архивных документов сделал попытку представить Сталина в качестве действовавшего по заранее составленному сценарию режиссера готовившегося им массового геноцида советских евреев, но не успевшего реализовать свои планы ${ }^{74}$. В этом ракурсе гибель Михоэлса рассматривается как один из этапов такого сценария.

Известный историк Г.В. Костырченко, посвятивший исследованию генезиса сталинского «госантисемитизма» докторскую диссертацию и целый ряд научных монографий, утверждает: «Главную роль в генезисе официального антисемитизма сыграл фактор единовластия Сталина» [Костырченко, 2014, с. 49, 51]. Костырченко полагает, что в современной исторической литературе нет «научно обоснованного ответа на ключевой вопрос о соотношении патологической параноической юдофобии и макиавеллиевского прагматизма в личном антисемитизме Сталина» [Костырченко, 2003a, с. 24], и он пытает-

74 Эта попытка была продолжена в целом ряде западных работ, в т. ч. пытающихся раскрыть «генеральный план заговора Сталина» против советской еврейской диаспоры, см., напр.: [Brent, Naumov, 2003]. 
ся дать такой ответ. В рамках этой схемы историк включает в нее гибель Михоэлса в качестве события, предваряющего кампанию по борьбе с космополитизмом и сопутствующие еврейские гонения в целом. По мнению исследователя, «к концу 40-х годов престарелый и страдавший от многочисленных хронических недугов диктатор окончательно превратился в патологического юдофоба, которому повсюду стали мерещиться происки и заговоры сионистов» [Костырченко, 2003a, с. 707], а «с “дела” Михоэлса - Аллилуевых политический сыск, осуществлявшийся МГБ, приобрел ярко выраженный антисемитский характер» [Костырченко 2003a, с. 387]. В своих многочисленных тематических публикациях Костырченко представляет гибель Михоэлса как следствие инспирированного Сталиным фальсифицированного расследования «“сионистского заговора” Михоэлса - Аллилуевых» (как названа одна из глав его работы): «главным виновником нагнетания государственного антисемитизма в стране и превращения аппарата МГБ в ударную силу этой политики был сам Сталин, что наглядно проявилось в истории физического устранения культурного лидера советского еврейства Соломона Михоэлса» [Костырченко, 2003, с. 388]. Здесь автор развивает и документально обосновывает версию сопоставления дела Аллилуевых с убийством Михоэлса и «делом ЕАК», которую впервые провела Л.А. Шатуновская, арестованная по «делу Аллилуевых». В своей мемуарной книге «Жизнь в Кремле» (1982) она посвятила отдельную главу теме «Дело Михоэлса - Аллилуевых», где впервые объединила в одно «дело» две «чистки» - Аллилуевых и ЕАК: «лишь очень немногие знают о том, что все эти аресты были звеньями одной цепи, этапами осуществления одного преступного сталинского замысла, целью которого было “окончательное решение” еврейского вопроса в СССР по гитлеровскому образцу» [Шатуновская, 1982, с. 239].

Однако, чтобы мотивировать этот «сталинский замысел» об устранении Михоэлса, Костырченко приходится не обращать внимания на даты. Так, известно, что во второй половине декабря 1947 г. Е.А. Аллилуева дала признательные показания о том, что ее знакомый И.И. Гольдштейн интересовался личной жизнью Сталина. Гольдштейн тотчас же был арестован, однако лишь в начале января 1948 г. от него выстроилась документально подкрепленная цепочка, ведущая к Михоэлсу. Этим документом сам исследователь считал «протокол допроса, который стал первым «официальным протоколом с момента ареста Гольдштейна $<\ldots>$ с признательными показаниями подследственного и его подписями $<\ldots>$ Датированный 9 января 1948 г., этот материал на следующий день был представлен Абакумовым Сталину <...> окончательное решение о его [Михоэлса] физическом устранении Сталин, скорей всего, принял 10 января 1948 г., когда Абакумов представил ему полученные под пыткой показания Гольдштейна о работе Михоэлса на американскую разведку по сбору информации о нем через родственников» [Костырченко, 2003a, с. 384, 388-389]. В тот же вечер эти показания были разосланы из сталинской канцелярии членам Политбюро [Костырченко, 2010, с. 159].

Однако эта «документально подтвержденная цепочка», иллюстрирующая мотивы Сталина в устранении Михоэлса, не соответствует другим фактам. В частности тому, что возглавляемая С.И. Огольцовым оперативная группа для проведения спецоперации по убийству Михоэлса приехала в Минск еще до его прибытия, т. е. 5-8 января ${ }^{75}$.

Для подтверждения своей новой гипотезы в специально посвященной убийству Михоэлса статье [Костырченко, 2003b] Костырченко вводит в рассмотрение целый ряд новых документов, связанных с гибелью Михоэлса, на основании которых приведенные выше версии Ж. Медведева и других признаются историком неверными, а выводы - устаревшими, поскольку «К сожалению, Жоресу Александровичу, видимо, просто не попались на глаза не так давно опубликованные первичные показания некоторых главных убийц

75 В «Записке» Л.П. Берии по «делу Михоэлса» в Президиум ЦК КПСС (от 2 апреля 1953 г.) приводятся следующие показания бывшего министра МГБ Белоруссии Цанавы: «При приезде Огольцов сказал нам, что по решению Правительства и личному указанию И.В. Сталина должен быть ликвидирован Михоэлс, который через день или два приезжает в Минск по делам службы» [Костырченко, 2005, с. 118]. 
Михоэлса - Огольцова, Цанавы, Шубнякова. Эти материалы, <...> со значительно большей, чем раньше, точностью позволяют реконструировать обстоятельства гибели знаменитого артиста» [Костырченко, 2003b].

Костырченко приводит собственную версию преступления, согласно которой арестованный по «делу Аллилуевых» И.И. Гольдштейн уже в конце декабря 1947 г., согласно цитируемому в статье свидетельству бывшего следователя Г.А. Сорокина (приводимому по «показаниям арестованного В.И. Комарова от 15-22 июля 1953 г.» со ссылкой на «Центральный архив ФСБ РФ» без указания архивного рубрикатора), «...показал о шпионской деятельности Михоэлса и о том, что он проявлял повышенный интерес к личной жизни главы Советского правительства в Кремле» [Костырченко, 2003b]. Поэтому «...к следующему своему визиту в Кремль к Сталину, который пришелся на вечер 23-го числа, Абакумов, скорей всего, уже имел на руках “признание” Гольдштейна» [Костырченко, 2003b].

В действительности здесь Костырченко приводит цитату из собственноручных показаний самого Г.А. Сорокина от 3 января 1954 г., опубликованных в составе хранящегося в РГАСПИ ${ }^{76}$ письма из Главной военной прокуратуры в ЦК КПСС о реабилитации осужденных по делу ЕАК от 12.12.1955 г. [Костырченко, 2005, с. 204]. Этим объясняется отсутствие выходных данных в отсылке цитаты на Центральный архив ФСБ РФ, как и в случае другого непроверенного новообретенного документа - «Объяснительной записки» С.И. Огольцова на имя Берии, - на основании которого, по вновь открывшимся из него обстоятельствам, Костырченко приходит к выводу, что «указание о ликвидации С.М. Михоэлса было дано Сталиным 27 декабря 1947 года» [Костырченко, 2005, с. 118], когда он встречался с вызванными в Кремль Абакумовым и Огольцовым. В специальной статье о «деле Михоэлса» исследователь диаметрально меняет свою позицию, перенося на конец декабря 1947 г. дату, когда, по его мнению, Сталину могло быть доложено о доказательствах шпионской деятельности Михоэлса, «выбитых» под пытками у Гольдштейна: «Этот нужный “хозяину” результат был озвучен в Кремле, скорей всего, 27 декабря, когда Абакумов снова предстал перед Сталиным, на сей раз в сопровождении своего заместителя С.И. Огольцова. < ..> Впоследствии, 18 марта 1953 года, в своем письменном объяснении Берии Огольцов сделает чрезвычайно важное сообщение о главном результате той встречи: “Во время беседы... товарищем Сталиным была названа фамилия Михоэлса и в конце беседы было им дано указание Абакумову о необходимости проведения специального мероприятия в отношении Михоэлса..."» [Костырченко, 2003b] ${ }^{77}$. Здесь и далее по тексту Костырченко ссылается на те самые новые документы, которые, по его мнению, не были должным образом учтены Ж. Медведевым и сторонниками других версий, в данном случае - на «Объяснительную записку» замминистра госбезопасности СССР по общим вопросам генерал-лейтенанта С.И. Огольцова, лично руководившего в Минске убийством Михоэлса. Основываясь на этих документах, Костырченко приходит к следующему основному тезису своей новой версии: «В противоположность тому, что утверждают Ж. Медведев и А. Борщаговский (инициатива в устранении Михоэлса исходила-де от Абакумова, а Сталин лишь дал “лицензию на отстрел”), именно кремлевский “хозяин” играл в этом деле первую скрипку. <..> Никак нельзя сбрасывать со счетов и показания Огольцова, свидетельствовавшего, что, вызвав его и Абакумова, “глава Советского правительства" дал им 27 декабря 1947 года не только указание о проведении “специального мероприятия в отношении Михоэлса”, но и уточнил при этом, что имеет в виду автомобильную катастрофу» [Костырченко, 2003b] ${ }^{78}$.

${ }^{76}$ РГАСПИ. Ф. 589. Оп. 3. Д. 15624. Л. 335-348.

${ }_{77}^{7 п}$ Опираясь на роман В. Левашова [Левашов, 2003], цитируется «Объяснительная записка» С.И. Огольцова Л.П. Берии «О подготовке и осуществлении “спецоперации" по устранению С.М. Михоэлса» от 18.03.1953, легитимизированная автором впоследствии: [Костырченко, 2005, c. $110-112]$.

${ }^{78}$ Также со ссылкой в качестве источника на роман В. Левашова: [Левашов, 2003, с. 400]. 
Таким образом, предложенная Г.В. Костырченко версия гибели Михоэлса основывается как на обобщающих выводах исследователя о периоде государственного антисемитизма, инициированном, по его мнению, старческой паранойей у Сталина, так и на привлечении неких новых архивно-документальных первоисточников, которые в этой связи будут критически рассмотрены далее.

\section{Результаты и их обсуждение: О достоверности первоисточников по «делу Михоэлса»}

В англоязычном исследовании проф. Дж. Кипа и А. Литвина современной историографии сталинизма, переведенном на русский язык, особое внимание уделяется вопросу о подлинности и достоверности источников сталинской эпохи как мемуарного, так и документального характера: «Проблема подлинности и достоверности источников возникла и при работе в архиве бывшего КГБ СССР <..> различные домыслы, существовавшие в следственных делах для осуждения арестованных, изначально были фальсифицированными документами. <..> Методика работы с ними чрезвычайно сложна. Ведь это крайне тенденциозные документы, в которых нуждается в проверке каждая фраза и слово» [Кип, Литвин, 2009, с. 213-214].

Рассмотрим в данном ракурсе новые документальные источники, вводимые Г.В. Костырченко для доказательства своей версии убийства Михоэлса и критики предшествующих объяснений события. Эта новая версия была опубликована автором в еженедельнике «Новости разведки и контрразведки» (2003. № 21-22. С. 7-10) и перепечатана в журнале «Лехаим» [Костырченко, 2003b, с. 39-48]. В дальнейшем источники, данные и выводы этой статьи были включены автором в последующие научные монографии.

Новая версия гибели С. Михоэлса рассматривается автором в этих публикациях на основании «Объяснительных записок» С.И. Огольцова и Ф.Г. Шубнякова к Л.П. Берии о их соучастии в убийстве С.М. Михоэлса, а также следственных показаний Л.Ф. Цанавы о «“спецоперации” по ликвидации С.М. Михоэлса», опубликованных в сборнике архивных первоисточников «Государственный антисемитизм в СССР» [Костырченко, 2005] самим Г.В. Костырченко как его составителем с одинаковой ссылкой «ЦАФСБ РФ. Архивная коллекция составителя. Копия» и отсылкой к первой публикации. Ей оказывается роман (политический триллер) В.В. Левашова «Убийство Михоэлса» [Левашов, 1998], из которого эти документы были переопубликованы в данном научном сборнике. Скажем, для примера, что этот роман начинается с еще одного документа: «Протокола допроса обвиняемого Джугашвили (Сталина) Иосифа Виссарионовича», и его автор никогда не претендовал на чисто документальный жанр романа.

В.В. Левашов в «Открытом письме историку Г.В. Костырченко» так объясняет происхождение в его романе вышеперечисленных архивных документов: «Издатель спросил: “Не хочешь заняться Михоэлсом? Ты же драматург, знаешь театр”. Как выяснилось, незадолго до этого он купил у какого-то отставного кагэбэшника ксерокопии допросов по делу Михоэлса. Вы, г-н Костырченко, в своей статье обильно цитируете по моей книге докладную записку полковника Шубнякова, заявив перед тем, что это недавно опубликованные документы из архива ФСБ. Нигде они не опубликованы, только в моем романе» [Левашов, 2004, с. 48-49]. Таким образом, отсылка Костырченко к Центральному архиву ФСБ РФ как источнику происхождения документов была официально опровергнута первым публикатором, а под их копиями, находящимися в «архивной коллекции составителя» сборника, т. е. Г.В. Костырченко, имеются в виду соответствующие страницы романа, действительно приведенные в сносках к документам на страницах сборника [Костырченко, 2005, с. 112-113, 115-116]. При этом сами первоначальные ксероксы документов не были затребованы для источниковедческого анализа этих исторических источников при их научной публикации. Дальнейшая судьба ксероксов также неизвестна. 
В связи с этим мы не имеем возможности исключить критику источников: в частности, фальсификацию источников на всех этапах их приобретения у неизвестного лица издательством «Олимп» по целому ряду причин. Вот лишь несколько из них.

1. Данные в «Объяснительной записке» от 18 марта 1953 г. на имя Берии полковника Ф.Г. Шубнякова противоречат его нотариально заверенным свидетельским показаниям по делу Михоэлса, представленным 6 июня 1995 года в Останкинский суд г. Москва по иску генерал-лейтенанта КГБ в отставке Е. Питовранова, а также его интервью журналу «Коммерсанть - Власть». Согласно этим показаниям, полковник Шубняков не участвовал в ликвидации С. Михоэлса, а поездку в Минск совершил для встречи с информатором (Голубовым-Потаповым) о настроениях и планах Соломона Михоэлса ${ }^{79}$.

2. Объяснительные записки С.И. Огольцова на имя Берии от 18 и 19 марта, а также Шубнякова от 18 марта 1953 г. были написаны ими до ареста, который произошел 3 апреля 1953 г. На дату написания записок Огольцов был отстранен от дел и «ходил в министерство писать объяснения, которые от него требовал Берия. Заметно нервничая, он называл кощунством то, что от него требовали» [Млечин, 2008]. В свою очередь, Ф.Г. Шубняков все еще занимал свой рабочий кабинет. Таким образом, они оба располагали всеми своими служебными записями и данными. Однако та же «Объяснительная записка» Огольцова составлена по типовому сценарию показаний арестованного, в которой ее автор не припоминает даже дат аудиенции со Сталиным, что является очевидным вымыслом: в то время о таком забывать было нельзя, тем более в отчете начальству. Так, С.И. Огольцов не давал показания, а докладывал Л.П. Берии: «По Вашему требованию докладываю об обстоятельствах проведенной операции по ликвидации главаря еврейских националистов Михоэлса в 1948 году. В ноябре-декабре (точно не помню) 1947 года Абакумов и я были вызваны в Кремль к товарищу Сталину И.В. <..> Во время беседы, в связи с чем, сейчас вспомнить затрудняюсь, товарищем Сталиным была названа фамилия Михоэлса <..> Примерно в первых числах января 1948 года Михоэлс выехал по делам театра в г. Минск. <..> Числа 6-7 января 1948 года я с группой товарищей <..> выехал на машине в Минск. <..> Операция была проведена успешно, если не ошибаюсь, в ночь с 11 на 12 января 1948 года» ${ }^{80}$. Отметим, что все даты в этой «Объяснительной записке», а в сущности - докладной на имя нового руководителя ведомства, указаны опытнейшим работником МГБ слегка ошибочно. Однако этот документ, составленный по наработанному сценарию показаний подследственного заключенного, не соответствует ситуации, в которой находился в тот момент С.И. Огольцов. Отстраненный новым руководством за неделю до того (11 марта 1953 г.) от должности Начальника ГРУ МГБ, он не был арестован и еще не лишился звания и службы в рядах МГБ, как и доступа к своим служебным записям или как минимум возможности посоветоваться о «подзабытом» с соучастником Ф.Г. Шубняковым в его рабочем кабинете.

\section{Заключение}

Представленный на примере «Объяснительных записок» Ф.Г. Шубнякова и С.И. Огольцова критический анализ новых «архивно-документальных» первоисточников по делу об убийстве С.М. Михоэлса демонстрирует их несоответствие с последующими нотариально заверенными показаниями Ф.Г. Шубнякова, а очевидная небрежность при указании дат встречи со Сталиным и спецопераций в докладной («Объяснительной записке») опытного аппаратчика МГБ генерал-лейтенанта С.И. Огольцова (ожидавшего на тот

79 Тяжба отставного генерала КГБ с прессой // Газета «Коммерсантъ» № 166 от 09.09.1995. С. 20. URL (доступ от 20.04.2020): <https://www.kommersant.ru/doc/117211>; Жирнов Е. 1998. Как убили Михоэлса // Коммерсантъ - Власть. № 2 (от 27 янв.). С. 38.

${ }^{80}$ Цит. по: Записка С.И. Огольцова Л.П. Берии о подготовке и осуществлении «спецоперации» по устранению С.М. Михоэлса от 18 марта 1953 г. [Костырченко, 2005, с. 110-112]. 
момент нового назначения) свидетельствует о намеренной тенденциозности либо фальсификации этого документа.

Как представляется, перечисленных в настоящей статье фактов достаточно, чтобы усомниться в легитимности документов, на основании которых историком Г.В. Костырченко была построена и обоснована новая версия убийства Соломона Михоэлса. Обзор полемики и критический анализ источников этой версии приводят к выводу, что, казалось бы, давно исследованное историками «дело Михоэлса» с очевидностью требует нового пересмотра в вопросе о том, какова в действительности была роль Сталина в решении судьбы великого актёра и режиссёра ${ }^{81}$.

\section{Список литературы}

1. Аллилуева С. 1990. Двадцать писем другу. М., Известия, 174.

2. Борщаговский А.М. 1994. Обвиняется кровь. М., Прогресс-Культура, 398.

3. Генина Е.С. 2011. Кампания по борьбе с космополитизмом в СССР в оценках отечественных исследователей 1990-х - начала 2000-х гг. Вестник КемГУ, 4: 22-27.

4. Кип Дж., Литвин А. 2009. Эпоха Иосифа Сталина в России. Современная историография / пер. с англ. Изд. 2-е. М., РОССПЭН, 328.

5. Кожинов В.В. 1999. Россия. Век ХХ (1939-1964): Опыт беспристрастного исследования. М., Алгоритм, 397.

6. Козлов В.А., Мироненко С.В., ред. 1994. Архив новейшей истории России: «Особая папка» И.В. Сталина: Каталог документов. Т. 1. М., Благовест, 394.

7. Костырченко Г.В. 2003а. Тайная политика Сталина. Власть и антисемитизм. 2-е изд., доп. М., Международные отношения, 784.

8. Костырченко Г.В. 2003b. «Дело Михоэлса». Новый взгляд. Дискутируя с Жоресом Медведевым. И не только с ним. Лехаим, 10: 39-48.

9. Костырченко Г.В., сост. 2005. Государственный антисемитизм в СССР. От начала до кульминации, 1938-1953. Под общ. ред. акад. А.Н. Яковлева. М., МФД: Материк, 592.

10. Костырченко Г.В. 2009. Сталин против «космополитов». Власть и еврейская интеллигенция в СССР. М., РОССПЭН, 415.

11. Костырченко Г.В. 2014. Доктрина «Старшего брата» и формирование государственного антисемитизма в СССР в свете идеологической и этнополитической трансформации сталинского режима в 1930-е годы. В кн.: Советские нации и национальная политика в 1920-1950-е годы. М., Полит. энциклопедия: 41-52.

12. Левашов В.В. 1998. Убийство Михоэлса. Роман. М., АСТ-Олимп, 480.

13. Левашов В.В. 2004. Кто творит мифы. Открытое письмо историку Г. Костырченко. Лехаим, 3: 48-49.

14. Лясс Ф.М. 2007. Последний политический процесс Сталина, или Несостоявшийся юдоцид. М. - Иерусалим, Филобиблон, 614.

15. Медведев Ж.А. Сталин и еврейская проблема. Новый анализ. М., Права человека, 2003. 288.

16. Млечин Л.М. 2008. История внешней разведки. Карьеры и судьбы. М., Центрполиграф, 509.

17. Соломон Михоэлс: Библиогр. указ. (1919-1999). 2003. М., РГБИ, 248.

18. Шатуновская Л.А. 1982. Жизнь в Кремле. New York, Chalidze, 351.

19. Эпштейн А.Д. 2014. «Национальный вопрос» между внутренней и внешней политикой. В кн.: Советские нации и национальная политика в 1920-1950-е годы. М., Полит. энциклопедия: $426-445$.

20. Brent J., Naumov V. 2003. Stalin's Last Crime: The Plot against the Jewish Doctors, 1948-1953. New York, Harper Collins, 399.

${ }^{81}$ Посвященный этому вопросу цикл статей публикуется нами в журнале «Знание. Понимание. Умение» (выпуски 1-3 за 2021 г.). 


\section{Referenses}

1. Allilueva S. 1990. Dvadtsat' pisem drugu [Twenty Letters to a Friend]. Moscow, Izvestiya Publ., 174 (in Russian).

2. Borshchagovskiy A.M. 1994. Obvinyaetsya krov' [The blood accuses]. Moscow, ProgressKul'tura Publ., 399 (in Russian).

3. Genina E.S. 2011. Kampaniya po bor'be s kosmopolitizmom v SSSR v otsenkakh otechestvennykh issledovateley 1990-kh - nachala 2000-kh gg. [The campaign against cosmopolitism in the USSR in the Appraisals of our country's researchers of the 1990s - the early 2000s.] Vestnik Kemerovskogo Gosudarstvennogo Universiteta, 4: 22-27 (in Russian).

4. Kip Dzh., Litvin A. 2009. Epokha Iosifa Stalina v Rossii. Sovremennaya istoriografiya [Stalinism. Russian and Western Views at the Turn of the Millenium] Transl. from Engl. 2rd. ed. Moscow, ROSSPEN Publ., 327 (in Russian).

5. Kozhinov V.V. 1999. Rossiya. Vek XX (1939-1964): Opyt bespristrastnogo issledovaniya [Russia. XX century (1939-1964)]. Moscow, Algoritm, 397 (in Russian).

6. Kozlov V.A., Mironenko S.V., red. 1994. Arkhiv noveyshey istorii Rossii: «Osobaya papka» I.V. Stalina: Katalog dokumentov [Archive of Contemporary Russian History, vol. 1: The «Special Files» for I.V. Stalin. A Catalogue of Documents]. Moscow, Blagovest Publ., 394 (in Russian).

7. Kostyrchenko G.V. 2003a. Taynaya politika Stalina. Vlast' i antisemitizm [Stalin's Secret Policy: The Regime and Anti- Semitism]. 2rd. ed. Moscow, Mezhdunarodnye otnosheniya Publ., 784 (in Russian).

8. Kostyrchenko G.V. 2003b. «Delo Mikhoelsa»: Novyy vzglyad. Diskutiruya s Zhoresom Medvedevym. I ne tol'ko s nim [«The investigation of Mikhoels». A New Look. Polemising with Zh. Medvedev and others]. Lekhaim, 10: 39-48 (in Russian).

9. Kostyrchenko G.V., sost. 2005. Gosudarstvennyy antisemitizm v SSSR. Ot nachala do kul'minatsii, 1938-1953 [State Anti-Semitism in the USSR: From the Beginning to Culmination, 1938-1953] / Pod obshch. red. akad. A.N. Yakovleva. Moscow, MFD: Materik, 592 (in Russian).

10. Kostyrchenko G.V. 2009. Stalin protiv «kosmopolitov». Vlast' i evreyskaya intelligentsiya v SSSR [Stalin against the «cosmopolitans». Power and Jewish intelligentsia in the USSR]. Moscow, ROSSPEN Publ., 415 (in Russian).

11. Kostyrchenko G.V. 2014. Doktrina «Starshego brata» i formirovanie gosudarstvennogo antisemitizma v SSSR v svete ideologicheskoy i etnopoliticheskoy transformatsii stalinskogo rezhima $\mathrm{v}$ 1930-e gody. [The doctrine of the «Big Brother» and the formation of state anti-Semitism in the USSR in the light of the ideological and ethno-political transformation of the Stalinist regime in the 1930s.] V kn.: Sovetskie natsii i natsional'naya politika v 1920-1950-e gody. [In: Soviet Nations and Nationality Policy from the 1920s to the 1950s.]. Moscow, Politicheskaya entsiklopediya Publ.: 41-52 (in Russian).

12. Levashov V.V. 1998. Ubiystvo Mikhoelsa. Roman [The killing of Mikhoels. Novel]. Moscow, AST-Olimp Publ., 480 (in Russian).

13. Levashov V.V. 2004. Kto tvorit mify. Otkrytoe pis'mo istoriku G. Kostyrchenko [Who creates myths. An open letter to the historian G. Kostyrchenko]. Lekhaim, 3: 48-49 (in Russian).

14. Lyass F.M. 2007. Posledniy politicheskiy protsess Stalina, ili Nesostoyavshiysya yudotsid [Stalin's Last Political Trial, or the Genocide that did not take place]. Moscow - Ierusalim, Filobiblon Publ., 612 (in Russian).

15. Medvedev Zh.A. Stalin i evreyskaya problema. Novyy analiz [Stalin and the Jewish Problem: A New Analysis]. Moscow, Prava cheloveka Publ., 288 (in Russian).

16. Mlechin L.M. 2008. Istoriya vneshney razvedki. Kar'ery i sud'by [History of foreign intelligence. Careers and destinies]. Moscow, Tsentrpoligraf Publ., 509 (in Russian).

17. Solomon Mikhoels: Bibliogr. ukaz. (1919-1999) [Bibliographic index (1919-1999)]. 2003. Ed. E.I. Alekseenkova, et al. Moscow, Publ. RGBI, 248 (in Russian).

18. Shatunovskaya L.A. 1982. Zhizn' v Kremle [Life in the Kremlin]. New York, Publ. Chalidze, 351 (in Russian).

19. Epshteyn A.D. 2014. «Natsional'nyy vopros» mezhdu vnutrenney i vneshney politikoy [«Ethnic question» between domestic and foreign policy. In: Soviet Nations and Nationality Policy from the 1920s to the 1950s.]. Moscow, Politicheskaya entsiklopediya Publ.: 426-445 (in Russian).

20. Brent J., Naumov V. 2003. Stalin's Last Crime: The Plot against the Jewish Doctors, 1948-1953. New York, Harper Collins Publ., 399. 
ИНФОРМАЦИЯ ОБ АВТОРЕ

Бисенгалиев Марат Кабдушевич, член МОО «Платоновское философское общество», независимый исследователь, г. Москва, Россия
INFORMATION ABOUT THE AUTHOR

Marat K. Bisengaliev, member of the Plato Philosophy Society, independent researcher. Moscow, Russia 